\title{
A method of transformation and current progress in transgenic research on cucumbers and Cucurbita species
}

\author{
Yoshihiko Nanasato ${ }^{1, *}$, Yutaka Tabei ${ }^{2, a}$ \\ ${ }^{1}$ Forest Bio-Research Center, Forestry and Forest Products Research Institute, Forest Research and Management \\ Organization, 3809-1 Ishi, Juo, Hitachi, Ibaraki 319-1301, Japan; ${ }^{2}$ Institute of Agrobiological Sciences, National Agriculture \\ and Food Research Organization, 2-1-2 Kannondai, Tsukuba, Ibaraki 305-8602, Japan \\ *E-mail: nanasato@affrc.go.jp Tel: +81-294-33-7348 Fax:+81-294-39-7306
}

Received December 8, 2019; accepted February 25, 2020 (Edited by N. Ohtsubo)

\begin{abstract}
Cucumber (Cucumis sativus L.) and Cucurbita species (squashes, pumpkins, and gourds), belonging to the Cucurbitaceae family, are among the major vegetable crops in the world. Transgenic approaches could contribute to the accumulation of new knowledge of these species and to the development of elite cultivars. Despite this, research reports using transformants of these species are very limited so far. One of the reasons for this may be that although there are effective transformation methods, these methods are not well known among researchers. In the present review, we describe efficient protocols for the transformation of cucumber and squash plants and mention possible pitfalls in and advice for following these protocols. In addition, we discuss the current progress of genetic transformation research using cucumbers and squash, including genome editing.
\end{abstract}

Key words: Cucumis sativus, Cucurbita species, genome editing, regeneration, transformation.

\section{Introduction}

The cucumber (Cucumis sativus L.), belonging to the Cucurbitaceae family, is commonly consumed as a vegetable in daily life. In 2017, the global production of cucumbers was 83.8 million tons (FAOSTAT, http://www. fao.org/faostat/en/\#home), of which China accounted for $77.4 \%$. In Japan, cucumbers are also popular, with 0.56 million tons produced in 2017, making Japan the 10th largest producer of cucumbers in the world. Cucumber plants suffer from several diseases, such as downy mildew, powdery mildew, anthracnose, and cucumber mosaic virus, which limit crop production. Developing resistance to these diseases is a major subject of cucumber plant breeding (King et al. 2012). However, it is difficult to improve the tolerance of cucumbers to pathogen attack by conventional breeding due to the plant's narrow genetic base, with a genetic variability of only 3-8\% (Plader et al. 2007). Squash (also pumpkin and gourd; Cucurbita pepo, C. maxima, and C. moschata) is another important vegetable in the Cucurbitaceae family. The global production of Cucurbita species reached 27.4 million tons in 2017 (FAOSTAT), primarily in China and India, which produced $29.1 \%$ and $18.7 \%$, respectively, of all squash worldwide. The vegetables are used for food, animal feed, and ornamental purposes. Also, they are used as rootstocks for other cultivated cucurbits, including watermelon, cucumber, and melon, to strengthen tolerance to low temperatures and soilborne diseases (Davis et al. 2008). In addition, they have a unique ability to take up more organic xenobiotics and persistent organic pollutants from soil than the other plant families (Otani et al. 2007).

Next-generation sequencing (NSG) data have been acquired for cucumber and Cucurbita species (Huang et al. 2009; Montero-Pau et al. 2018; Sun et al. 2017). The analysis of this data allows for the discovery of new genes and regulatory sequences and confirmation of their positions, and makes available large collections of molecular markers. Genome-wide expression studies provide breeders with an understanding of the molecular basis of complex traits, such as the ripening process, phloem transport, disease resistance, cold tolerance, and fruit quality. Transformation approaches for cucumber and Cucurbita species would contribute to both basic science and molecular breeding.

Abbreviations: ABA, abscisic acid; BA, 6-benzyladenine; $\mathrm{GA}_{3}$, gibberellic acid; GFP, green fluorescent protein; HPT, hygromycin phosphotransferase; NPTII, neomycin phosphotransferase.

${ }^{a}$ Present address: Strategic Planning Headquarters, National Agriculture and Food Research Organization, 3-1-1 Kannondai, Tsukuba, Ibaraki 3058517, Japan

This article can be found at http://www.jspcmb.jp/

Published online June 18, 2020 
The successful transformation of cucumber plants with Agrobacterium rhizogenes was first reported in 1986 (Trulson et al. 1986). A particle bombardment method of transformation was also reported in 1992 (Chee and Slightom 1992). In recent years, Agrobacterium tumefaciens-mediated transformation has been primarily used for cucumbers. Transgenic cucumber lines have been produced for the analysis of genes involved in pathogen resistance, stress tolerance, and sex determination (Narusaka et al. 2013; Wang et al. 2014; Zhang et al. 2014). Despite this, to our knowledge, there are few reports on stable transformation of squash to date. Tricoli et al. (1995) first reported the development of transgenic yellow crookneck squash lines (C. pepo) that exhibit multiple virus resistance, but the detail of their method remains enigmatic. The second article about the transformation of $C$. pepo was published in 2008 and reported a transformation efficiency of $0.7 \%$. The successful transformation of C. moschata was achieved in 2011 (Nanasato et al. 2011), with a transformation efficiency of $2.7 \%$. The transformation efficiency could be increased to $9.2 \%$ by applying vacuum infiltration to wounded explants to enhance Agrobacterium access to the cells in deeper layers (Nanasato et al. 2013b). We successfully transformed C. pepo and C. maxima using the same method.

Here, we present some information for researchers who are interested in tissue culture and transformation of cucumber and/or squash but have never worked with such approaches. The information given is based on our protocols for the transformation of cucumber and squash (Nanasato et al. 2011, 2013a, b; Nanasato and Tabei 2012, 2015; Tabei and Nanasato 2012) (Figure 1, Table 1). Even if specific procedures are followed, tissue culture and

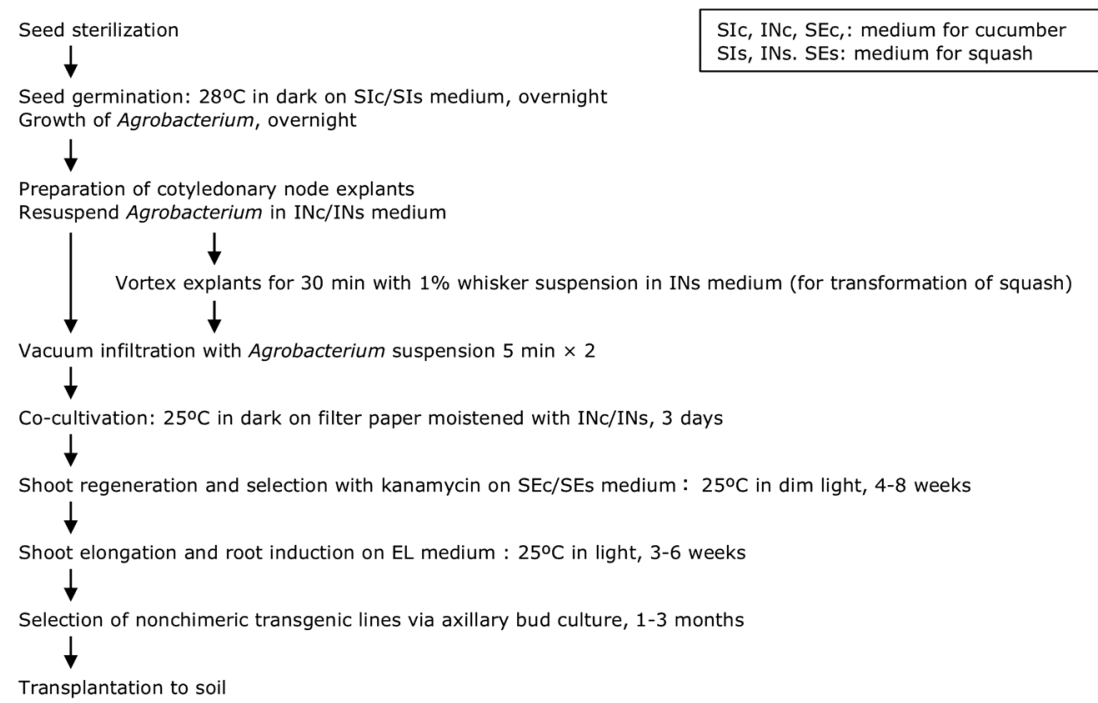

Figure 1. Steps for the transformation of cucumber (cv. Shinhokusei No.1) and squash (cv. Heiankogiku) plants via direct-shoot organogenesis from cotyledonary explants. The compositions of shoot induction (SI) medium, inoculation (IN) medium, selection (SE) medium, and elongation (EL) medium are shown in Table 1. The concentration of Agrobacterium $\left(\mathrm{OD}_{600}\right)$ is adjusted to 0.5 in INc for cucumber and 0.1 in INs for squash.

Table 1. Composition of culture media used for transformation of cucumber and squash.

\begin{tabular}{|c|c|c|c|}
\hline Plant species & Designation & Purpose of use & Composition \\
\hline \multirow[t]{3}{*}{ Cucumber } & SIc & Shoot induction & $\begin{array}{l}\text { MS salts and vitamins }+2 \mathrm{mgl}^{-1} \mathrm{BA}+1 \mathrm{mgl}^{-1} \mathrm{ABA}^{\S}+3 \%(\mathrm{w} / \mathrm{v}) \text { sucrose }+0.8 \%(\mathrm{w} / \mathrm{v}) \\
\text { agar, pH 5.7-5.8 }\end{array}$ \\
\hline & INc & Inoculation & $\begin{array}{l}\text { MS salts and vitamins }+2 \mathrm{mgl}^{-1} \mathrm{BA}+1 \mathrm{mgl}^{-1} \mathrm{ABA}^{\S}+10 \mathrm{mMMES}+3 \%(\mathrm{w} / \mathrm{v}) \text { sucrose } \\
+200 \mu \mathrm{M} \text { acetosyringone } \mathrm{e}^{\S} \mathrm{pH} 5.2\end{array}$ \\
\hline & SEc & Selection & SIc medium $+50 \mathrm{mgl}^{-1}$ kanamycin $^{\S}+10 \mathrm{mgl}^{-1}$ meropenem ${ }^{\S}$, pH 5.7-5.8 \\
\hline \multirow[t]{3}{*}{ Squash } & SIs & Shoot induction & MS salts and vitamins $+1 \mathrm{mgl}^{-1} \mathrm{BA}+3 \%(\mathrm{w} / \mathrm{v})$ sucrose $+0.8 \%(\mathrm{w} / \mathrm{v})$ agar, $\mathrm{pH} 5.7-5.8$ \\
\hline & INs & Inoculation & $\begin{array}{l}\text { MS salts and vitamins }+1 \mathrm{mgl}^{-1} \mathrm{BA}+10 \mathrm{mMMES}+3 \%(\mathrm{w} / \mathrm{v}) \text { sucrose }+500 \mu \mathrm{M} \\
\text { acetosyringone } \mathrm{s}^{\S}, \mathrm{pH} 5.2\end{array}$ \\
\hline & SEs & Selection & SIs medium $+50 \mathrm{mgl}^{-1}$ kanamycin $^{\S}+10 \mathrm{mgl}^{-1}$ meropenem $^{\S}$, pH 5.7-5.8 \\
\hline $\begin{array}{l}\text { Common in cucumber } \\
\text { and squash }\end{array}$ & EL & Shoot elongation & 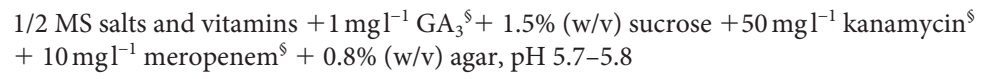 \\
\hline
\end{tabular}

The $\mathrm{pH}$ of all media in Table 1 is adjusted with $\mathrm{NaOH}$ before addition of agar and autoclave. ${ }^{\S}$ Add aseptically to sterilized media that has been cooled to approximately $55^{\circ} \mathrm{C}$. ABA, abscisic acid; BA, 6-benzyladenine; $\mathrm{GA}_{3}$, gibberellin $\mathrm{A}_{3}$; MES, 2-(N-morpholino)ethanesulfonic acid; MS, Murashige-Skoog 
transformation often fail. We identify possible pitfalls in documented protocols and provide suggestions to avoid them. Finally, we discuss the current progress of genetic transformation research on cucumbers and squash, including genome editing.

\section{Preparation of explants for efficient regeneration}

Various tissues, such as true leaves, hypocotyl, stem nodes, and cotyledons, have been used as explants in the regeneration and transformation of cucumber plants (Nishibayashi et al. 1996; Miao et al. 2009; Trulson et al. 1986; Ziv and Gadasi 1986). In 1994, Colijn-Hootmans et al. reported efficient regeneration of cucumber plants using the proximal end of young seedlings (1 day of preculture) (Colijn-Hooymans et al. 1994). The use of the proximal region of cotyledons as explants is often seen in the literature (Figure 2A, B) (Hu et al. 2017; Selvaraj et al. 2006, 2010; Vengadesan et al. 2005). After 1 day of preculture, cotyledons are detached from seeds using forceps. The distal parts of cotyledon are removed because they have no regeneration ability. The preparation process for squash explants is similar to that for cucumbers: immature cotyledons are excised from 1-day-old seedlings. However, especially in the case of squashes, care should be taken not to remove the
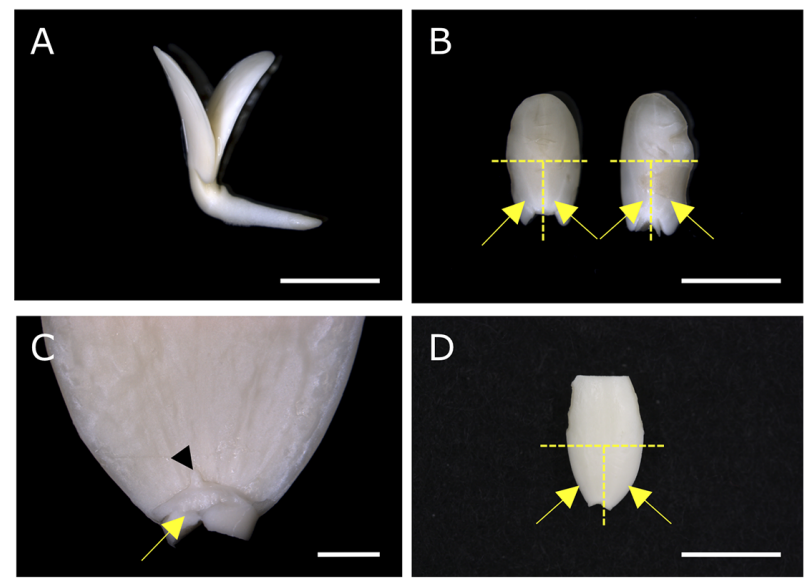

Figure 2. Preparation of explants. Seed coats are removed using a scalpel and forceps. The peeled seeds are sterilized for $10 \mathrm{~min}$ in a $1 \%$ $(\mathrm{w} / \mathrm{v})$ sodium hypochlorite aqueous solution supplemented with one drop of Tween 20 with occasional agitation and then rinsed five times with sterile distilled water. The sterilized seeds are germinated at $28^{\circ} \mathrm{C}$ in dark for 1 day on the corresponding shoot-inducing medium. (A) A germinating cucumber seed, incubated in the dark for 1 day at $28^{\circ} \mathrm{C}$. Scale bar $=5 \mathrm{~mm}$. (B) Detached cucumber cotyledons. The proximal regions marked with arrows are used as explants. Scale bar $=5 \mathrm{~mm}$. (C) Proximal region of squash cotyledon. Yellow arrow indicates the junction of the cotyledon and hypocotyl. Black arrowhead indicates shoot apex. Scale bar $=1 \mathrm{~mm}$. (D) Detached squash cotyledons. As in cucumbers, the proximal regions are used as explants. Scale bar $=5 \mathrm{~mm}$. All pictures are adapted from Nanasato and Tabei (2012) and Tabei and Nanasato (2012), courtesy of Kagaku-Dojin, Kyoto, Japan. cotyledonary nodes around the shoot apex by breaking off the hypocotyl (Figure 2C), because only this part retains regeneration ability, as reported previously (Ananthakrishnan et al. 2003; Kathiravan et al. 2006; Lee et al. 2003; Zhang et al. 2008). For the purpose of generating more transgenic shoots, we use the proximal parts of cotyledons, cut longitudinally into two pieces, as explants (Figure 2B, D). However, some groups use the whole proximal parts of cotyledons as explants.

\section{Plant hormones for regeneration}

Although indirect organogenesis via somatic embryogenesis has been reported in cucumber plants (Burza et al. 2006; Chee 1990; Raharjo and Punja 1994), direct organogenesis has an advantage over indirect organogenesis in terms of time for regeneration. Murashige-Skoog (MS) medium (Murashige and Skoog 1962) with 1-2 $\mathrm{mgl}^{-1}$ 6-benzyladenine (BA) and 0.5$1.0 \mathrm{mgl}^{-1}$ abscisic acid (ABA) has been shown to lead to efficient regeneration of cucumber plants (Tabei et al. 1998; Zhang et al. 2017), whereas in squash, the addition of ABA caused necrosis (Nanasato et al. 2011). For squash cultivars, MS medium with $1 \mathrm{mgl}^{-1}$ BA was used for regeneration (Kathiravan et al. 2006; Nanasato et al. 2013b; Zhang et al. 2008).

\section{Strains of Agrobacterium tumefaciens}

The use of particle bombardment for gene transfer was reported in cucumber plants (Kodama et al. 1993; Schulze et al. 1995). Currently, an Agrobacteriummediated transformation method is more commonly used for gene transfer; strains EHA105 and LBA4404 can be used similarly in the transformation of cucumber and squash. In our case, EHA 105 harboring the pBI121derived binary vector was cultured with Luria-Bertani

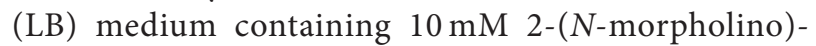
ethanesulfonic acid (MES), $50 \mathrm{mgl}^{-1}$ kanamycin, $25 \mathrm{mgl}^{-1}$ chloramphenicol, $25 \mathrm{mgl}^{-1}$ rifampicin and $20 \mu \mathrm{M}$ acetosyringone, $\mathrm{pH} 5.2$ at $28^{\circ} \mathrm{C}$ until the optical density at $600 \mathrm{~nm}\left(\mathrm{OD}_{600}\right)$ reached $0.4-0.8$. The bacterial cells were pelleted and resuspended in inoculation medium (IN), and the concentration of Agrobacterium $\left(\mathrm{OD}_{600}\right)$ was adjusted to 0.5 in INc for cucumber and 0.1 in INs for squash (Table 1).

\section{Physical treatments performed during Agrobacterium infection}

Physical treatments, such as vacuum infiltration and wounding, during Agrobacterium infection are the most important factors in the successful transformation of cucumber and squash (Figure 3A-C). These treatments contribute to increased Agrobacterium inoculation 

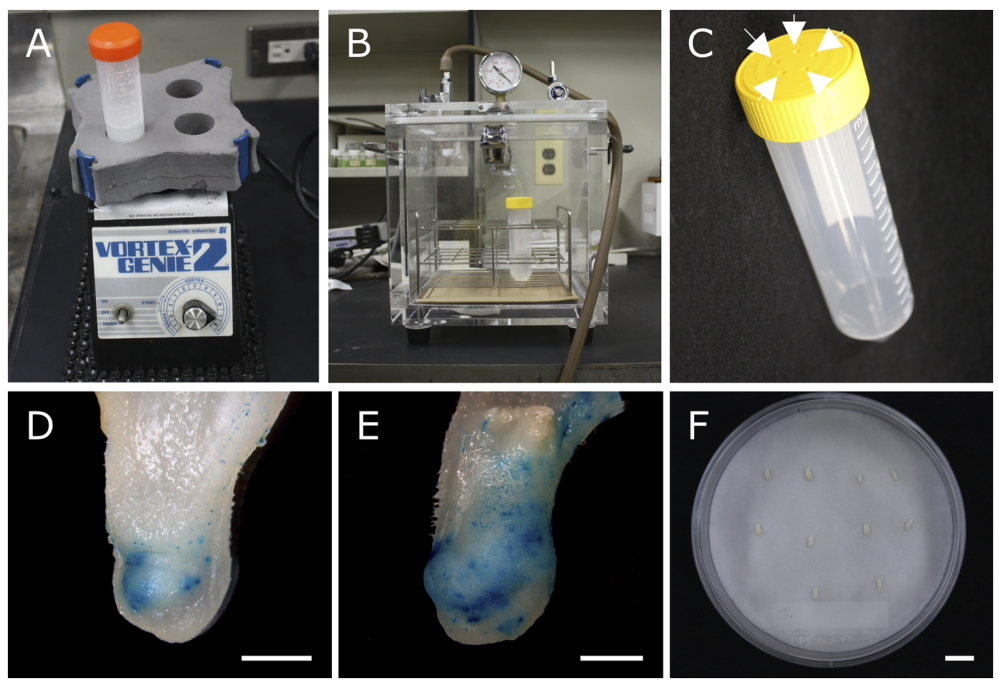

Figure 3. Special treatments for infection with Agrobacterium. (A) Vortex apparatus and $50 \mathrm{ml}$ tube with $1 \%$ whisker suspension. (B) Desiccator connected to a vacuum pump. (C) $50 \mathrm{ml}$ tube with a vent cap. White arrows indicate vent holes for gas exchange. GUS activity in squash explants without wounding treatment (D) and after wounding treatment by vortexing explants with $20 \mathrm{ml}$ of $1 \%(\mathrm{w} / \mathrm{v}$ ) whisker suspension in $50 \mathrm{ml}$ tube for $30 \mathrm{~min}$ before Agrobacterium infection (E). Scale bars $=2 \mathrm{~mm}$. (F) Cocultivation of cucumber explants on three pieces of stacked filter paper moistened with $5.5 \mathrm{ml}$ inoculation medium at $25^{\circ} \mathrm{C}$ in the dark for 3 day. Scale bar $=1 \mathrm{~cm}$. Pictures A-C, and $\mathrm{F}$ are adapted from Nanasato and Tabei (2012) and Tabei and Nanasato (2012), courtesy of Kagaku-Dojin, Kyoto, Japan.

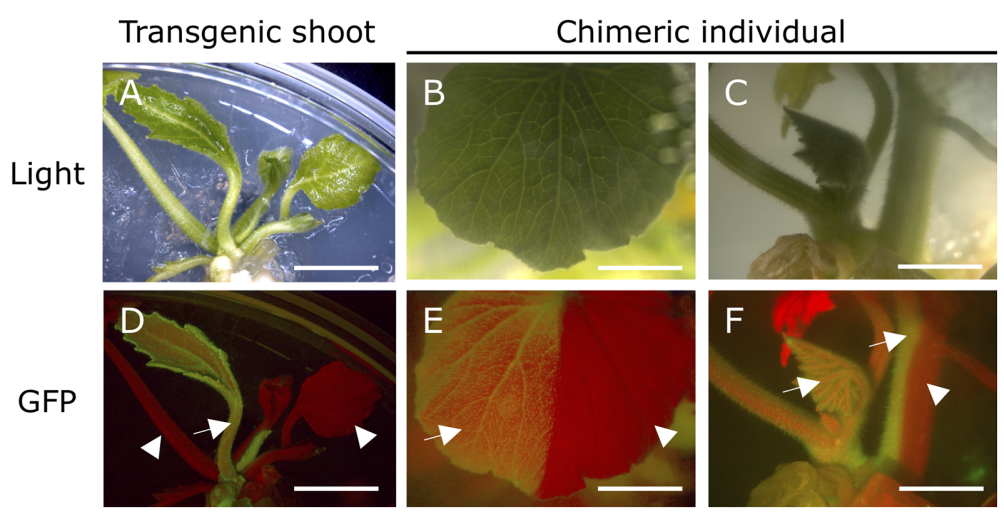

Figure 4. GFP-expressing transgenic squash lines. A transgenic shoot under visible light (A) and excitation light for GFP fluorescence (D). Strong GFP fluorescence was observed in the solid transgenic shoot indicated by a white arrow in D, while autofluorescence in red was observed in nontransgenic shoots, indicated by white arrowheads. A sectorial chimeric individual under visible light (B, C) and excitation light for GFP fluorescence (E, F). White arrows in $\mathrm{E}$ and $\mathrm{F}$ indicate transgenic cells exhibiting GFP fluorescence, and white arrowheads in $\mathrm{E}$ and $\mathrm{F}$ indicate nontransgenic cells. Scale bar $=5 \mathrm{~mm}$.

efficiency in deeper layer cells, which seem to have the potential of organogenesis (Nanasato et al. 2013b). The effectiveness of vacuum infiltration has been confirmed in reports from other research groups (Hu et al. 2017; Zhang et al. 2017). Whiskers, which are white needle-like crystals with very high tensile strength, can be used to wound squash explants (Figure 3D, E) (Nanasato et al. 2011, 2013b). In addition, the cocultivation of explants on filter paper moistened with coculture medium can significantly contribute to improved transformation efficiency (Figure 3F).

\section{Selection and rooting of nonchimeric transgenic lines}

A combination of the neomycin phosphotransferase II (NPTII) gene and kanamycin has been frequently used for the selection of transformants. The regeneration of escape shoots is almost unavoidable, even under stringent selection conditions (Figure 4A, D). Therefore, the use of visual markers, such as green fluorescent protein (GFP), is the key for obtaining cucumber and squash transformants. Furthermore, transgenic shoots developed via direct organogenesis are often chimeric. Chimeric individuals are composed of a mixture of transformed and nontransformed cells. The use of visual markers is effective for the discrimination of 
sectorial chimeras (Figure 4B, C, E, F). Root elongation in chimeric individuals is frequently inhibited in media containing antibiotics. Multiple rounds of axillary bud induction in the selection medium are a powerful way to generate solid transformants from chimeric individuals.

Supplementation of the growth media with low concentrations of auxins, such as indole-3-butyric acid (IBA) and 1-naphthaleneacetic acid (NAA), to promote rooting is recorded in some research papers (Sarmento et al. 1992; Vasudevan et al. 2007; Zhang et al. 2008). However, auxin-induced chlorosis of the regenerated leaves was also reported ( $\mathrm{Hu}$ et al. 2017). In many cases, it seems unnecessary to add auxins to promote rooting. After shoots with vigorous roots grow four to five nodes (about $10 \mathrm{~cm}$ in height), the shoots should be transplanted to soil as described previously (Nanasato and Tabei 2012, 2015; Tabei and Nanasato 2012).

\section{Application of genome editing technology in cucumber and squash}

Since the announcement of CRISPR/Cas9 technology in 2012 (Jinek et al. 2012), genome editing technology has been spreading rapidly in plant functional genomics research and crop improvement. To date, two research groups have reported successful genome editing in cucumber plants using the CRISPR/Cas9 system (Hu et al. 2017; Sherman et al. 2016). Both groups succeeded in producing transgene-free null segregant lines via crossing. The CRISPR/Cas9 system was also used for functional analysis of a gene encoding NADPH oxidase in C. moschata (Huang et al. 2019).

\section{Conclusion}

Research on cucumber and squash has been improved due to the development of genome information. Cucumber is one of the potential candidates for a model plant of the Cucurbitaceae family and would provide new scientific knowledge through molecular analysis. In addition, genome editing technology could contribute to the rapid breeding of cucumber and squash. Transformation techniques will play an increasingly important role in the progress of basic science and molecular breeding. In this review, we describe methods of transformation of cucumber and squash plants based on reports we published previously. We emphasize that the concentration of plant hormones for regeneration and conditions for Agrobacterium infection should be adjusted according to the plant cultivar treated. We hope that this review will contribute to the development of Cucurbitaceae plant research and molecular breeding.

\section{Acknowledgements}

We wish to thank to Ms. I. Kawaguchi, Ms. T. Tachibana, Ms. A. Sugai, Ms. J. Shioda, Ms. Y. Ozeki, and Ms. K. Masuda for their technical assistance. We acknowledge the financial supports rendered by Assurance of Safe Use of Genetically Modified Organisms (grant number 312) from the Ministry of Agriculture, Forestry and Fisheries of Japan (MAFF), and Genomics for Agricultural Innovation (grant number GMB-0002) from MAFF. Enago (https://www.enago.jp/) corrected the manuscript.

\section{References}

Ananthakrishnan G, Xia X, Elman C, Singer S, Paris HS, Gal-On A, Gaba V (2003) Shoot production in squash (Cucurbita pepo) by in vitro organogenesis. Plant Cell Rep 21: 739-746

Burza W, Zuzga S, Yin Z, Malepszy S (2006) Cucumber (Cucumis sativus L.). In: Wang K (ed) Agrobacterium Protocols, 2nd edition. Methods in Molecular Biology, Vol. 343. Humana Press, New Jersey, pp 427-438

Chee PP (1990) High frequency of somatic embryogenesis and recover of fertile cucumber plants. HortScience 25: 792-793

Chee PP, Slightom JL (1992) Transformation of cucumber tissues by microprojectile bombardment: Identification of plants containing functional and non-functional transferred genes. Gene 118: 255-260

Colijn-Hooymans CM, Hakkert JC, Jansen J, Custers JBM (1994) Competence for regeneration of cucumber cotyledons is restricted to specific developmental stages. Plant Cell Tissue Organ Cult 39: 211-217

Davis AR, Perkins-Veazie P, Sakata Y, López-Galarza S, Maroto JV, Lee SG, Huh YC, Sun Z, Miguel A, King SR, et al. (2008) Cucurbit grafting. CRC Crit Rev Plant Sci 27: 50-74

Hu B, Li D, Liu X, Qi J, Gao D, Zhao S, Huang S, Sun J, Yang L (2017) Engineering non-transgenic gynoecious cucumber using an improved transformation protocol and optimized CRISPR/ Cas9 system. Mol Plant 10: 1575-1578

Huang S, Li R, Zhang Z, Li L, Gu X, Fan W, Lucas WJ, Wang X, Xie B, Ni P, et al. (2009) The genome of the cucumber, Cucumis sativus L. Nat Genet 41: 1275-1281

Huang Y, Cao H, Yang L, Chen C, Shabala L, Xiong M, Niu M, Liu J, Zheng Z, Zhou L, et al. (2019) Tissue-specific respiratory burst oxidase homolog-dependent $\mathrm{H}_{2} \mathrm{O}_{2}$ signaling to the plasma membrane $\mathrm{H}^{+}$-ATPase confers potassium uptake and salinity tolerance in Cucurbitaceae. J Exp Bot 70: 5879-5893

Jinek M, Chylinski K, Fonfara I, Hauer M, Doudna JA, Charpentier E (2012) A programmable dual-RNA: Guided DNA endonuclease in adaptive bacterial immunity. Science 337: 816-822

Kathiravan K, Vengedesan G, Singer S, Steinitz B, Paris HS, Gaba $\mathrm{V}$ (2006) Adventitious regeneration in vitro occurs across a wide spectrum of squash (Cucurbita pepo) genotypes. Plant Cell Tissue Organ Cult 85: 285-295

King SR, Davis AR, Wehner TC (2012) Classical genetics and traditional breeding. In: Wang Y, Behera TK, Kole C (eds) Genetics, Genomics and Breeding of Cucurbits. CRC Press, pp 61-92

Kodama H, Irifune K, Kamada H, Morikawa H (1993) Transgenic roots produced by introducing $\mathrm{Ri}$-rol genes into cucumber cotyledons by particle bombardment. Transgenic Res 2: 147-152

Lee YK, Il Chung W, Ezura H (2003) Efficient plant regeneration via organogenesis in winter squash (Cucurbita maxima Duch.). 
Plant Sci 164: 413-418

Miao MM, Xu R, Zheng LJ, Zhou HL, Zhang ZD, Cheng H (2009) High-efficiency Agrobacterium tumefaciens-mediated transformation of cucumber (Cucumis sativus L.) using stem nodes as explants. J Hortic Sci Biotechnol 84: 199-203

Montero-Pau J, Blanca J, Bombarely A, Ziarsolo P, Esteras C, Martí-Gómez C, Ferriol M, Gómez P, Jamilena M, Mueller L, et al. (2018) De novo assembly of the zucchini genome reveals a whole-genome duplication associated with the origin of the Cucurbita genus. Plant Biotechnol J 16: 1161-1171

Murashige T, Skoog F (1962) A revised medium for rapid growth and bio assays with tobacco tissue cultures. Physiol Plant 15: 473-497

Nanasato Y, Konagaya K, Okuzaki A, Tsuda M, Tabei Y (2011) Agrobacterium-mediated transformation of kabocha squash (Cucurbita moschata Duch) induced by wounding with aluminum borate whiskers. Plant Cell Rep 30: 1455-1464

Nanasato Y, Konagaya K, Okuzaki A, Tsuda M, Tabei Y (2013a) Improvement of Agrobacterium-mediated transformation of cucumber (Cucumis sativus L.) by combination of vacuum infiltration and co-cultivation on filter paper wicks. Plant Biotechnol Rep 7: 267-276

Nanasato Y, Okuzaki A, Tabei Y (2013b) Improving the transformation efficiency of Cucurbita species: Factors and strategy for practical application. Plant Biotechnol 30: 287-294

Nanasato Y, Tabei Y (2012) Cucumber. In: Tabei Y (ed) Protocols for Plant Transformation. Kagaku-Dojin, Kyoto, pp 197-205 (in Japanese)

Nanasato Y, Tabei Y (2015) Cucumber (Cucumis sativus L.) and kabocha squash (Cucurbita moschata Duch). In: Wang K (ed) Agrobacterium Protocols, 3rd edition. Methods in Molecular Biology, Vol. 1223. Springer, New York, pp 299-310

Narusaka M, Kubo Y, Hatakeyama K, Imamura J, Ezura H, Nanasato Y, Tabei Y, Takano Y, Shirasu K, Narusaka Y (2013) Interfamily transfer of dual NB-LRR genes confers resistance to multiple pathogens. PLoS One 8: e55954

Nishibayashi S, Kaneko H, Hayakawa T (1996) Transformation of cucumber (Cucumis sativus L.) plants using Agrobacterium tumefaciens and regeneration from hypocotyl explants. Plant Cell Rep 15: 809-814

Otani T, Seike N, Sakata Y (2007) Differential uptake of dieldrin and endrin from soil by several plant families and Cucurbita genera. Soil Sci Plant Nutr 53: 86-94

Plader W, Burza W, Malepszy S (2007) Cucumber. In: Pua E-C, Davey MR (eds) Transgenic Crops IV. Springer Berlin Heidelberg, Berlin, Heidelberg, pp 181-199

Raharjo SHT, Punja ZK (1994) Regeneration of plantlets from embryogenic suspension cultures of pickling cucumber (Cucumis Sativus L. CV. Endeavor). Vitr Cell Dev Biol-Plant 30: $16-20$

Sarmento GG, Alpert K, Tang FA, Punja ZK (1992) Factors influencing Agrobacterium tumefaciens mediated transformation and expression of kanamycin resistance in pickling cucumber. Plant Cell Tissue Organ Cult 31: 185-193

Schulze J, Balko C, Zellner B, Koprek T, Hänsch R, Nerlich A, Mendel RR (1995) Biolistic transformation of cucumber using embryogenic suspension cultures: Long-term expression of reporter genes. Plant Sci 112: 197-206

Selvaraj N, Kasthurirengan S, Vasudevan A, Manickavasagam M,
Choi CW, Ganapathi A (2010) Evaluation of green fluorescent protein as a reporter gene and phosphinothricin as the selective agent for achieving a higher recovery of transformants in cucumber (Cucumis sativus L. cv. Poinsett76) via Agrobacterium tumefaciens. Vitr Cell Dev Biol Plant 46: 329-337

Selvaraj N, Vasudevan A, Manickavasagam M, Ganapathi A (2006) In vitro organogenesis and plant formation in cucumber. Biol Plant 50: 123-126

Sherman A, Brumin M, Chandrasekaran J, Wolf D, Pearlsman M, Gal-On A, Klap C, Leibman D, Arazi T (2016) Development of broad virus resistance in non-transgenic cucumber using CRISPR/Cas9 technology. Mol Plant Pathol 7: 1140-1153

Sun H, Wu S, Zhang G, Jiao C, Guo S, Ren Y, Zhang J, Zhang H, Gong G, Jia Z, et al. (2017) Karyotype stability and unbiased fractionation in the paleo-allotetraploid Cucurbita genomes. Mol Plant 10: 1293-1306

Tabei Y, Kitade S, Nishizawa Y, Kikuchi N, Kayano T, Hibi T, Akutsu K (1998) Transgenic cucumber plants harboring a rice chitinase gene exhibit enhanced resistance to gray mold (Botrytis cinerea). Plant Cell Rep 17: 159-164

Tabei Y, Nanasato Y (2012) Kabocha squash. In: Tabei Y (ed) Protocols for Plant Transformation. Kagaku-Dojin, Kyoto, pp 211217 (in Japanese)

Tricoli DM, Carney KJ, Russell PF, McMaster JR, Groff DW, Hadden KC, Himmel PT, Hubbard JP, Boeshore ML, Quemada HD (1995) Field evaluation of transgenic squash containing single or multiple virus coat protein gene constructs for resistance to cucumber mosaic virus, watermelon mosaic virus 2, and zucchini yellow mosaic virus. Bio/Technology 13: 1458-1465

Trulson AJ, Simpson RB, Shahin EA (1986) Transformation of cucumber (Cucumis sativus L.) plants with Agrobacterium rhizogenes. Theor Appl Genet 73: 11-15

Vasudevan A, Selvaraj N, Ganapathi A, Choi CW, Manickavasagam M, Kasthurirengan S (2007) Direct plant regeneration from cucumber embryonal axis. Biol Plant 51: 521-524

Vengadesan G, Anand RP, Selvaraj N, Perl-Treves R, Ganapathi A (2005) Transfer and expression of nptII and bar genes in cucumber (Cucumis satavus L.). Vitr Cell Dev Biol-Plant 41: $17-21$

Wang H, Sui X, Guo J, Wang Z, Cheng J, Ma S, Li X, Zhang Z (2014) Antisense suppression of cucumber (Cucumis sativus L.) sucrose synthase 3 (CSSUS3) reduces hypoxic stress tolerance. Plant Cell Environ 37: 795-810

Zhang Y, Zhang X, Liu B, Wang W, Liu X, Chen C, Liu X, Yang S, Ren $\mathrm{H}$ (2014) A GAMYB homologue CsGAMYB1 regulates sex expression of cucumber via an ethylene-independent pathway. $J$ Exp Bot 65: 3201-3213

Zhang Y, Zhou J, Wu T, Cao J (2008) Shoot regeneration and the relationship between organogenic capacity and endogenous hormonal contents in pumpkin. Plant Cell Tissue Organ Cult 93: 323-331

Zhang Z, Li X, Ma S, Shan N, Zhang X, Sui X, zhang (2017) A protocol for Agrobacterium-mediated transformation of cucumber (Cucumis sativus L.) from cotyledon explants. Protoc Exch 107.

Ziv M, Gadasi G (1986) Enhanced embryogenesis and plant regeneration from cucumber (Cucumis sativus L.) callus by activated charcoal in solid/liquid double-layer cultures. Plant Sci 47: $115-122$ 